\title{
The Capacity of Local Government in South Asia
}

\author{
Amitava Basu \\ Intercontinental Consultants and Technocrats Private Limited, New Delhi, India \\ cross $^{\text {ref }}$ http://dx.doi.org/10.5755/j01.ppaa.14.3.13436
}

\begin{abstract}
South Asia, covers 7 countries - Bangladesh, Bhutan, India, Maldives, Nepal, Pakistan and Sri Lanka; and accounts for about 34\% of Asia's population or over $16.5 \%$ of the world's population and are home to a vast array of people. South Asia has experienced a long period of robust economic growth, averaging $6 \%$ a year. The proportion of poor is lower now in South Asia than any time since 1981. Yet, it is the poorest region in the world after Sub-Saharan Africa. Across the region, democracy has been weakened, corruption has increased and the rights of citizens are denied. In April 1993, the Heads of States of South Asia unanimously committed to poverty eradication. It opened up new political space in South Asia and was the beginning of decentralisation of government authority in this region. Although political decentralisation has taken place, fiscal and administrative decentralisation lag behind in most of the South Asian countries. Decentralisation has resulted in establishment of local government institutions, provision of their constitutional recognition and empowerment. As part of democratization, the local bodies are having elected representatives, who determine the policies and strategies and executive wing implements and carries out day-to-day functions. The foremost challenge for effective local governance is enhancing the capabilities of local bodies and staffing by officials who are adequately trained and equipped for the tasks assigned to them. Also, to be successful at local level it needs to be backed by political will and clear legal responsibilities for local government. South Asia is in midst of transition and reforms for democratic decentralization. The road is long and tortuous, but is the only 'one-way' path to alleviation of poverty, inclusive growth, and participatory governance.
\end{abstract}

Keywords: decentralization, democratization, governance, capacity-building

Raktažodžiai: decentralizacija; demokratizacija; valdymas; gebèjimu vystymas.

\section{Introduction}

South Asia, covering the southern part of the Asian continent, comprises the countries of Bangladesh, Bhutan, India, Maldives, Nepal, Pakistan, and Sri Lanka. In 
terms of land and topography, though South Asia is made up of three topographic regions: (i) the Himalaya, Karakorum, and Hindu Kush mountain ranges and their southern slopes, (ii) the Indo-Gangetic plain, and (iii) the Deccan plateau. South Asia is a single geographical unit, but it is a region of complex and pluralistic characteristics having ethnic and linguistic differences and religious diversity.

Such difference and diversity clearly determine the fact that local governments, their roles, structures and problems have some common features, but also very many critical differences. The goal of this paper is to present the current situation of local government in South Asia and to derive main lessons for future improvements of local government capacities in the region.

\section{Main characteristic of the South Asia Region}

With the seven countries ${ }^{1}$, the area covers about 4.48 million $\mathrm{km}^{2}$ (1.7 million $\mathrm{mi}^{2}$ ), which is $10 \%$ of the Asian continent or $2.4 \%$ of the world's land surface area. These countries account for about $34 \%$ of Asia's population (or over $16.5 \%$ of the world's population) and are home to a vast array of people. The area, population and population density of the South Asian countries is presented in Table 1.

Table1. Area, Population \& Population Density of South Asia

\begin{tabular}{|l|c|c|c|}
\hline Country & Area $(\mathbf{k m 2})$ & Population (2009-2012) & Density (per km2) \\
\hline Bangladesh & 147,570 & $152,518,015$ & 1,099 \\
\hline Bhutan & 38,394 & 697,000 & 18 \\
\hline India & $3,287,240$ & $1,210,193,422$ & 382 \\
\hline Maldives & 298 & 396,334 & 1,330 \\
\hline Nepal & 147,181 & $26,620,080$ & 200 \\
\hline Pakistan & 796,095 & $180,440,000$ & 225 \\
\hline Sri Lanka & 65,610 & $20,277,597$ & 319 \\
\hline
\end{tabular}

Source: Statistical Year Book for Asia and the Pacific 2014

The population in the region totalled nearly 1.6 billion inhabitants, representing nearly $25 \%$ of the world's total population spread over less than $4 \%$ of the world's surface. From a demographic point of view, South Asia is dominated by India, which alone has a population of 1.21 billion, but there are two other densely populated countries in this region, namely, Pakistan and Bangladesh, with population of 180 and 147 million respectively as per latest available data. South Asia also includes countries with small population such as Bhutan, with only 697,000 inhabitants and the Maldives with just 396,000.

\footnotetext{
${ }^{1}$ According to some school of thoughts, Afghanistan does not fall in South Asia. However, Afghanistan is admitted into South Asian Association for Regional Cooperation (SAARC) forum. However, for the purpose of this paper Afghanistan is not covered in the main section, but a brief note on it is provided as a separate Annexure.
} 
According to the report released by World Bank in 2011, the annual population growth rate in 2010 in South Asia was $1.46 \%$. Only Sri Lanka in this region has a growth rate less than the world's average. India has a share of $17.54 \%$ in world's population. Pakistan, the sixth most populous country in the world has a growth rate of $2.04 \%$ in 2010 . Bangladesh, the seventh most populous country in the world, contributes $2.35 \%$ to world's population. Nepal, Bhutan and Maldives make smaller contribution.

As a diversified geographic zone, there are sharp contrasts in South Asia between the mountains of Nepal, for instance, and the lowlands of the Maldives Islands or the Ganges Delta in Bangladesh. This geographic diversity goes hand in hand with demographic, economic and social heterogeneity.

The demographic challenges confronting South Asia are those of developing countries faced with a major population increase. They are the challenges of education, housing, health care and employing a growing - sometimes rapidly growing - population. These countries have to fight against poverty while ensuring that the economic growth needed to improve the lives of the people does not result in serious environmental damage. However, there are sharp contrasts between these countries, be it in terms of demographic growth, population density, mortality and fertility rates, urbanization or literacy.

\section{Economy and Human Development}

South Asia has experienced a long period of robust economic growth, averaging 6\% a year over the past 20 years. Yet, it is the poorest region in the world after SubSaharan Africa. According to the United Nation's Multidimensional Poverty Index (MPI), South Asia leads the world in poverty, housing between $52 \%$ and $62 \%$ of the bottom billion. Most of the rest live in Sub-Saharan Africa, which is home to 33\% to $39 \%$ of the poorest billion people. However, the strong growth has translated into declining poverty and impressive improvements in human development. The percentage of people living on less than $\$ 1.25$ a day fell in South Asia from $61 \%$ to $36 \%$ between 1981 and 2008. The proportion of poor is lower now in South Asia than any time since 1981. Still, the South Asia region is home to many of the developing world's poor. According to the World Bank's most recent poverty estimates, about 571 million people in the region survive on less than $\$ 1.25$ a day, and they make up more than $44 \%$ of the developing world's poor. The Human Development Index (HDI) of the countries in South Asia is presented in Table 2.

Sri Lanka has the highest Gross Domestic Product (GDP) per capita in the region. India is the largest economy in the region (US\$ 1.97 trillion) and makes up almost $82 \%$ of the South Asian economy. It is the world's tenth largest in nominal terms and third largest by purchasing power adjusted exchange rates. Pakistan has the next largest economy and the fifth highest GDP per capita in the region, followed by Bangladesh and then by Sri Lanka which is the fourth largest economy in the region. 
Table2. South Asian Countries by HDI Index

\begin{tabular}{|c|c|l|}
\hline Rank & Country & HDI New 2013 Estimates for 2012 \\
\hline \multicolumn{3}{|c|}{ High Human Development } \\
\hline 1. & Sri Lanka & 0.715 \\
\hline \multicolumn{3}{|c|}{ Medium Human Development } \\
\hline 2. & Maldives & 0.661 \\
\hline 3. & India & 0.554 \\
\hline 4. & Bhutan \\
\hline \multicolumn{3}{|c|}{ Low Human Development } \\
\hline 5. & Bangladesh \\
\hline 6. & Pakistan & 0.515 \\
\hline 7. & Nepal & 0.515 \\
\hline
\end{tabular}

Source: United Nations Development Program Report on Human Development Index, 2013

As referenced in the January 2013 Global Economic Prospects, growth in South Asia weakened to an estimated 5.4\% in 2012 from $7.4 \%$ in 2011, mainly as a result of a slowdown in India, where GDP growth was forecast to be $5.4 \%$ in the fiscal year ending in March 2013. Weak global demand exacerbated region-specific factors, including subdued investment growth, electricity shortages, policy uncertainties, and a weak monsoon. Regional GDP is projected to grow by $5.7 \%$ in the 2013 calendar year, $6.4 \%$ in 2014, and $6.7 \%$ in 2015, driven by improvement in export demand, policy reforms in India, stronger investment activity, and normal agricultural production.

According to the World Bank estimates, $70 \%$ of the South Asian population and about $75 \%$ of South Asia's poor live in rural areas and most rely on agriculture for their livelihood. The 2013 Global Hunger Index (GHI) states that hunger in South Asia prevails, with its 20.7 hunger index making the region's situation "alarming". Corruption and lack of initiative on the part of the government has been one of the major reasons for building up to this situation.

\section{Democracy and Governance}

Most countries in the region experienced colonization before becoming independent sovereign states. After attaining independence, political systems in the region have produced many forms of government: democratic, socialist, military and monarchical. Military rule, monarchy and centralized autocratic political systems are accepted within the framework of democracy in the region. However, the systems lack visions and directives for the development of minorities and the marginalized. Thus, the fate of South Asian minorities and the marginalized in general and women in particular has been ignored - despite various political experiments in governance. Further, South Asia is characterized by its large population, growing poverty, weak 
governance structures and feeble democratic institutions, increasing militarization and sectarianism.

Across the region, democracy has been weakened, corruption has increased and the rights of citizens are denied. Economic liberalization and globalization have contributed to a further increase in income inequalities, whereby more privileged groups have enjoyed the fruits of development by controlling the limited resources.

The rule of law in South Asia is largely disregarded and undermined in terms of economic rights and equality for all, despite the fact that South Asian Association for Regional Cooperation (SAARC) member states $^{2}$ are signatories of international instruments. Lawlessness plays a dominant role in promoting bad governance in most South Asian countries. As a result, ordinary people have been deprived of civil liberties, security and socio-economic rights.

Despite its cultural diversity, strong feudal and traditional values and patriarchal cultural practices, which are common characteristics across the region, have hindered capacity building and the improvement and take-up of opportunities for women, and tribal, ethnic and minority communities in South Asia. This has prevented marginalized communities, including women, from participating in political decisionmaking processes.

The stage of crisis has been manifested by pervasive nepotism and corruption, misappropriation of state funds, an absence of transparency and accountability in public administration, a lack of respect for the rule of law and ethical behaviour in public life and reluctance to delegate administrative or financial powers to grassroots organizations.

Reform of the situation is only possible if the people assert themselves and demand that the country be governed and not ruled, and that issues of good governance are seriously addressed. Public campaigns to secure the right to information could start a mass movement. Democratic governance begins with commitment to and respect for the sovereignty of citizens irrespective of religious, racial, linguistic, class, caste and gender diversities in an accountable, inclusive and participatory process. A radical reconstitution of governance is therefore required to make democracy functional. Only democratic governance based on strong democratic principles can bring about desirable change. This can be achieved by devolving constitutional power to the citizens and actively involving marginalized people in decisions-making processes.

\section{Decentralization Processes in South Asia}

This part of the paper describes the evolution process of decentralization of government hierarchy in South Asia and explains the main driving force for

\footnotetext{
${ }^{2}$ The Islamic Republic of Afghanistan, the People's Republic of Bangladesh, the Kingdom of Bhutan, the Republic of India, the Republic of Maldives, the Federal Democratic Republic of Nepal, the Islamic Republic of Pakistan and the Democratic Socialist Republic of Sri Lanka.
} 
emergence of empowering local governments. It also presents the key challenges that face decentralization and the local government in the region.

\section{Evolution of Decentralization in South Asia}

In addition to the general data described in the previous section, South Asia also had too long depended on external inspiration and hegemonies. In retrospect these strategies ended up with 'soft' societies, where the majority of people including the poor, women, and young people became alienated. The welfare societies became unsustainable. The creativity, innovativeness and holistic problem-solving approach to life, which has always been a characteristic of South Asian societies was ignored. De-alienation of people had to be an important dimension in the process of building self-reliance and human security.

There were sharpening contradictions and polarization between the rich and poor in South Asia and the link between poverty and violence. Multifaceted crisis was increasingly visible-demographic pressures, extensive erosion of the natural resource base, large scale unemployment of educated youth and youth alienation, low growth, increasing lack of credibility of the state and ethnic and gender conflicts. The inadequacy and disarray in conventional development thinking and action was understood. It was realized by the governments of the region that social transformation and structural changes are required. It had to go beyond the simplistic growth and redistribution and human face models. Structural change was more than mere financial and budgetary discipline and ad hoc redistributive justice. The much needed social transformation has to be conceived as a long reform process implying a complex chain of long and short time frames - not a one-shot 'big bang' revolution.

In 1992, Independent South Asian Commission on Poverty Alleviation ${ }^{3}$ was established by the Heads of State of SAARC. At the Seventh SAARC Summit in Dhaka, in April 1993, the Heads of State unanimously endorsed the Poverty Commission recommendations and reiterated their commitment with the Dhaka Consensus to continue to accord the highest priority to the eradication of the worst forms of poverty, within a ten-year period. This commitment was repeated in the SAARC Summits of 1995 and 1997. In other words, the SAARC Heads of State accepted ownership of the strategic thrust. This was the Dhaka Consensus of the Heads of State of SAARC constituted a major coherent response to reflect the strong compulsions to bring poverty to the centre stage of national concern in South Asia with innovative action. It also opened up new political space in South Asia for a political approach to poverty eradication through social mobilization and participation

\footnotetext{
3 Report of the Independent South Asian Commission on Poverty Alleviation, "Meeting the Challenge", SAARC Secretariat, Kathmandu, November 1992. Members of the Commission were Krishna Prased Bhattarai (Chairman), Ponna Wignaraja (Vice Chairman), Shaikh Maqsood Ali, Fazle Hasan Abed, Sangay Ngedup, Jigmi Singay, K. R. Venugopal, S. R. Hashim, Abdul Sattar Moosa Didi, Hassan Sobir, Shreekrishna Upadhyay, Madhukar S. J. B. Rana, Safdar Hussain Kazmi, Sohaib Sultan Khan and Warnasena Rasaputram.
} 
of the people in development. This was the beginning of decentralization of government authority in this region.

\section{Decentralization Processes}

Political decentralization usually requires changes in constitutions and legal frameworks. Several South Asian countries in one way or another have moved ahead with political decentralization. Bangladesh, Bhutan, India, Maldives, Nepal, Pakistan, and Sri Lanka have adopted changes in their constitutions and legal framework to redefine the roles, functions and functionaries of local governments.

There are different driving forces as to why these countries have pursued (or are pursing) decentralization. The primary reason for this initiative, however, lies in the economic rationale that local governments, being closer to their constituencies, may be more responsive to local needs, and consequently, provide public services more efficiently.

Bangladesh, has had a long history of rural local governments (the Union Parishads), although with limited powers and a long history of community based systems of service delivery and Non-Governmental Organizations (NGOs). Bangladesh has been a parliamentary democracy since a constitutional amendment in 1991.The Constitution of Bangladesh, in Articles 59 and 60, has laid down a framework concerning local government bodies. After the elections in December 2008 , the expectations have been that decentralization will be one of the pillars to enhance democracy and to reduce corruption.

In Bhutan, the 9th Five-year Plan (2002/03-2006/07) and 10th Five-year Plan (2008/09-2012/13) focused on the needs of the Gewogs (rural communities) and Dzongkhags (districts). Devolution of resources and decision-making powers to the local level is a key aim of the Plans.

The 73rd and 74th Constitutional Amendments in India, issued in 1992, enshrined devolution in the Constitution of India and mandated that states hold regular elections and transfer funds and functions to the third tier of governmenturban (i.e. municipalities) and rural (i.e. panchayats) local governments.

The constitutional sanction to local government has raised expectations and aspirations. Local Body elections have disproved the myth that women are uninterested in public life. There is a near unanimity among women that they would have been unable to get into these bodies were it not for statutory representation. Significantly, about 40 percent of women panchayat (rural local body) members belong to marginalized groups in the villages.

Local government in Maldives provided for by the Decentralization Act 2010 and the Local Council Election Act 2010, and it is enshrined in the Constitution (Chapter VIII). The Local Government Authority Department of the Ministry of Home Affairs is responsible for local government, which comprises 20 atoll councils, 66 island councils and two city councils (Malé and Addu). Local government is in two tiers with the atoll councils in the first tier and the island and city councils in the 
second. Local elections are held every three years. The local authorities have revenueraising powers, charging fees or rent for services provided, as well as receiving transfers from national government. They are also empowered to raise finance to fund development projects. Atoll councils are responsible for managing projects in the Atoll Development Plan not assigned to an island council. The island and city councils are responsible for primary health care, pre-school education, adult education, utilities, waste disposal, pest control and roads.

In Nepal, the Local Self Government Act (LSGA) of 1999 defined three types of local bodies and endowed them with some revenue powers and expenditure responsibilities. Recently, Nepal has undergone a delicate transition from monarchy to the model of a federal state. In this context, the roles of the different tiers of government, the number of tiers, and the nature of fiscal flows are still under way to define the future of the decentralization strategy. Local bodies are becoming increasingly involved in local service provision and users' groups in the management of local resources and services. For example, thousands of user groups have been given authority to manage local forests. Decentralized governance has produced positive impacts in terms of people's participation in governance, poverty reduction, empowerment of women and weaker social groups, and involvement of nongovernmental organizations and the private sector in delivery of social and production services.

Local people have been able to solve individual as well as community problems on their own. The number of women in leadership roles in community-based activities is increasing. The provision for representation of women in local governance has made about 40000 women local government representatives.

Pakistan embarked upon a far-reaching devolution plan in 2000-2001 to transfer central powers to new local governments. Devolution was aimed at injecting new blood into the political system, including marginalized citizens in formal politics, and contributing to strong accountability between new politicians and local electorates. A three-tier federated local government system was set up in every district of the country as an integral part of provincial governments. The local government system integrates rural with urban local governments and the bureaucracy with the local governments so that the district administration and police are answerable to the elected head of the district government. Women, peasants, workers and minorities have been given representation at each level of local government. Citizen Community Boards provide a mechanism for motivating and involving the local community in local development. The local government system has been implemented in all the four provinces of Pakistan and direct elections have been held to fill more than 120000 Union Council seats.

Decentralization has made the district and tehsil (sub-district) the hub of all development and service delivery activities. The head of the district government is an elected representative and not a bureaucrat.

The 13th Constitutional Amendment of Sri Lanka in 1987 called for substantial decentralization reform in the public sector and in service delivery. The reforms were 
meant to be part of the peace strategy aimed at addressing the issues of ethnicity and local autonomy in the context of the civil war4. Improved service delivery is an implicit goal. Local governments are the third tier under the purview of the provincial councils created. However, local authorities still have limited fiscal and administrative authority and the Government structure, by and large, remains centralized.

The organization and administrative structure of the local government have certain commonalities across South Asia in terms of institutions and authorities formed and empowered at local level - i.e. urban and rural. The local government usually has at the apex level the district followed, especially in Bangladesh, India, Pakistan, and Sri Lanka, the sub-district at intermediate level and at the grass-root level is the urban local body or village body. The local bodies are given a constitutional recognition. Further, as part of democratization, the local bodies are having elected representatives. The elected wing determines the policies and strategies and executive wing implements and carries out day-to-day functions. The local bodies have been transferred a number of functions from basic civic services to provision of livelihood facilities, shelter and the likes. Also, to ensure people participation, reservation of posts in the local bodies is made for women, the economically marginalized, indigenous people and minority communities.

\section{Ways and Initiatives Focusing on Improving Local Government Capacities}

It needs to be underlined that local government is not only practical but also effective in taking development directly to the people in this region. Therefore, it is imperative to make local government sustainable and help to reduce poverty and provide a variety of vital public services. Hence, a certain level of state intervention is necessary in order to ensure equitable distribution of the benefits, and social inclusivity. Further, local governments elected and monitored by the electorate who understand their rights or is sensitized enough to do so, local governments can be good medicine against bad governance, corruption, and ensuring efficient service delivery. In other words, local government is not just important for the delivery of services, but is crucial for the economic and social development of the people of South Asia, especially in the context of its present socio-economic situation. Therefore, for development to be successful at local level it needs to be backed by political will, clear legal responsibilities for local government, appropriate instruments, and ensuring that it is grounded in local conditions.

\footnotetext{
${ }^{4}$ The Sri Lankan Civil War was a conflict fought on the island of Sri Lanka. Beginning on 23 July 1983, there was an intermittent insurgency against the government by the Liberation Tigers of Tamil Eelam (the LTTE, also known as the Tamil Tigers), an independent militant organisation which fought to create an independent Tamil state called Tamil Eelam in the north and the east of the island. After a 26-year military campaign, the Sri Lankan military defeated the Tamil Tigers in May 2009, bringing the civil war to an end.
} 
However, it has been borne out by practical experience that local government institutions can be of real service to the people only if they are staffed by officials who are adequately trained and equipped for the tasks assigned to them. And, the other aspect, equally important, is that local government institutions must operate within the overall framework of policy determined by the central government. This element of cohesion is absolutely essential to ensure the absence of contradictions and the delivery of substantial benefits to the people.

The rationale behind strengthening capacity of the Local Government Institutions (LGI) is that it would help in deepening local democracy, upholding socio-economic equity and ensuring provisions of public services to citizens. Capacity in the context of democratic decentralization refers to the totality of inputs required by the local government institutions to fulfil their purposes.

Capacity development of LGIs aims to ensure that such institutions are able to function as institutions of self-governance. For this, the intervention can be at individual, institutional and societal levels. Individual capacity development focuses on enhancing inherent human potential and aims at developing conditions that allow individuals to build and enhance existing knowledge and skills, improves learning and helps them to adapt to change. Secondly, institutional capacity in LGIs refers to the ability of these institutions to develop and manage its systems and procedures by aiding and modernizing the pre-existing institutions; promoting mechanisms of transparency, accountability and participation; improving LGIs ability to relate to the external environment to find innovative mechanisms to promote 'smart privatization' and hold private service providers accountable to the poor. Thirdly, societal capacities development aims to be inclusive of all the actors and stakeholders of LGIs, particularly including the citizens, the poor and marginalized, as the primary stakeholders of LGIs. Hence, at the societal level capacity development initiatives need to establish more interactive public administration that considers people's feedback, and removes societal and institutional constraints to allow people's involvement in affairs of LGIs.

In Bangladesh, the government and the Community Service Organizations (CSOs) are both involved in providing capacity development support to LGIs. The government provides capacity development support through different government institutions to elected representatives and related government officials by providing training on the roles and management of the LGIs. The CSOs focus on improving governance at the local level. The CSO approach is more inclusive, intensive and wider in which the local communities are also included in the capacity development activities.

Improving pedagogy and quality of facilitators is a necessary requirement for the success of the capacity development effort. Bangladesh's Cascade Based Training project focused on the training of trainers (TOT) and used organizational strengthening approach and leadership development approach. A cascade-based training module was developed and an 'expert panel' supervised by National Institute 
of Local Government (NILG) was constituted to prepare the Local Governance Support Project (LGSP) training module and training material.

In order to ensure that LGIs are effective institutions of self-governance, capacity development interventions can be at individual, institutional and societal levels. As is evident, in Bangladesh's Strengthening Local Governance project, the initiative of creating Lok Morchas at all three levels of Union, Upazila and District enabled horizontal and triangular linkage of LGI, public officials and local community and further helped in developing a micro-macro linkage between local and national levels. Hence, interventions at the institutional and societal levels created linkages and mobilized the local society, which helped to establish a participatory and accountable local governance system.

The participatory process of planning and decision-making were also found to be established in the Bangladesh's Strengthening Local Governance project.

In India, the Ministry of Rural Development (MoRD) and Ministry of Panchayati Raj (MoPR) through identified national institutes, plans and organizes training of trainers program for all the State Institutes of Rural Development (SIRDs) faculty members. They in turn train both the elected and non-elected functionaries of the Panchayati Raj Institutions (PRI) in every state. Apart from these various CSOs also provide capacity development support. Moreover, for urban local bodies, there are several accredited training institutes across the country and the Ministry of Urban Development (MoUD) has taken number of initiatives to build capacity at urban local body level.

Knowledge management is another concern in the capacity development of LGIs. The 'Panchayat Resource Centre' initiative in India is an example of addressing this concern in which four different approaches of partnership approach, communication approach, leadership approach and knowledge management approach were utilized.

A good example to address a capacity development need that requires building partnerships and networks is the 'Pre-Election Voters Awareness Campaign' $(P E V A C)$ in India. In this the approaches of partnership and networks, and communication were utilized.

Use of technology is evident in the 'satellite communication model' (SATCOM) of Gujarat, India, where the e-learning approach to capacity development, has had an extensive reach.

Leadership development is a very crucial part of capacity development in LGIs. 'Panchayati Raj Jagrukta Abhiyan' (PRJA) in India - a campaign on awareness building for the elected representatives of LGIs is an example of this where communication and leadership development approaches were made use of in this project.

The Village Development Program (VDP) in Nepal works for poverty reduction by forming community organizations (COs). The program aims to support local communities and local governments in institutionalizing community organizations as self-governing and self-sustaining institutions to facilitate participatory development. 
In Pakistan, capacity development training was mandatory under the Local Government Ordinance, 2001. Following the ordinance, various training programs were organized by the Provincial Governments for the elected and non-elected LGI functionaries in collaboration with the National Reconstruction Bureau (NRB).

In Pakistan's Capacity Building of Women in Local Governance Institutions: Gujranwala and Rahim-yar-Khan District project, partnership and networks approach and leadership development approach were applied. Besides the National Reconstruction Bureau (NRB) which trained a group of master trainers, who further trained district based groups of local trainers, three other organizations were involved in imparting training to women councillors and three groups of councillors representing workers and peasants' communities.

Pakistan's Capacity Development of Women project, created spaces to develop women elected representatives as community leaders. The number of women elected as heads of representative local councils increased tremendously and women councillors were also seen actively pursuing various community problems.

In Sri Lanka, under the National Policy on Local Government, 1999, capacity development was viewed as a requirement to make LGIs an integral part of the system of representative government. Sri Lanka Institute for Local Governance (SLILG) is responsible for planning and implementing the national program for capacity development of LGIs throughout the country. This national program includes preparing and delivering annual training programs for skill development and also preparing, educational courses and conducting training programs in response to specific requests.

Sri Lanka's Managing Solid Waste project is an example of intervention at individual and societal levels where both elected representatives and Pradeshiya Sabha officers were provided training and programs were also conducted to involve the community at large to bring about a system change in solid waste management. Sri Lanka's Dehiwela-Mt Lavinia Municipal Council project helped the municipal employees to identify problems of poor service delivery and feasible pragmatic solutions, which enhanced their living standards and led to better service delivery with respect to provisions of infrastructure facilities by the Council.

The Lok Morchas also helped to solve many personnel issues through continuous lobbying and voice articulation. The issue of transparency was addressed in all the three committees and services were found to be better. An improvement in services was also observed in the Pakistan's Karachi City District Government project, offering exemplary services even during natural calamities.

Establishing vertical and horizontal linkages and enabling interface between the people and the governance institutions is an important component for the success of local governance units. Power to the grassroots will come only if this link is made strong, and capacity development has a crucial role to play in this. Such linkages were developed in in Bangladesh's Strengthening Local Governance project and proved to be an effective tool in bringing the desired level of change. Hence, capacity development cannot be viewed through a narrow prism of training of individuals but 
also needs to focus on developing capacity at institutional and societal levels, with a particular focus on building horizontal linkages. Further, effort needs to be made for enhancing the material base for the sustenance of LGIs which requires capacity enhancement interventions that focus on mobilizing local resources.

For promoting effective participation, the need is to build networks and collaborations of different actors at regional and local levels to take up issues of participation and accountability through local government. Hence, capacity development has to be an integrated approach.

Other focus areas need to include developing individual local leadership, developing skills that are necessary to functions in LGIs, programs for promoting attitudinal change in officials at all levels, creating institutional mechanisms so that the LGIs function as transparent and accountable institutions, and most significantly building an active, engaged and informed citizenry.

\section{Key Future Challenges to Increase Local Government Capacities in South Asia}

In general, although political decentralization has taken place, fiscal and administrative decentralization lag behind in most of the South Asian countries. We provide some examples. In Bangladesh, local governments lack adequate financial resources for the development of basic rural infrastructure. There is a need to improve the resource base of local government institutions through sharing of tax and non-tax revenue, and provision of grants and other development assistance by the central government. Local government bodies also need support for building their management capacities.

Similarly, in India, local governments face impediments to discharging their responsibilities, the primary being an inadequate resource base. Local government representatives and nearly a million local government officials assigned or closely connected with the local government's bodies also need capacity-building training.

In Nepal, although the LSGA has devolved authority to local bodies, central line agencies are reluctant to put this in practice. Local bodies continue to be treated as subordinate agents of local development rather than autonomous units of local selfgovernance.

While the new system in Pakistan provides for more responsiveness and accountability, the process of establishing supporting institutions is slow which is affecting service delivery. Yet, local revenue mobilization is insufficient for the sustainability of the local government bodies and comprehensive capacity-building is required for local government institutions.

The devolution process in Sri Lanka has found shortcomings in the structure and working of decentralized governance in the country. Social and economic indicators strongly suggest that decentralization has not been effective in reducing inter-regional income and social development disparities. The main reason is the lack of sufficient political will at the centre and an inadequately developed legal framework which have 
made the system unwieldy and ineffective with high "transaction costs". This is reflected in the insufficient delegation of powers from the centre to the provinces and from the provinces to local authorities. There is also insufficient utilization of existing technical and management capacities.

\section{Main Challenges: SWOT Analysis}

The move towards decentralization and empowerment of local government in different countries of South-Asia has strengths, weaknesses, opportunities and threats that are, by and large, common across these countries.

As the main strengths we can mention (on the base of information in this paper, but also many other sources) following - unified legislation that integrates the different tiers of government; division of roles and functions between central government agencies and local bodies by devolution of a wide range of sectoral functions, though there are instances of such devolution of functions instead of by delegation and de-concentration; fiscal provision made for local bodies to generate their own resources, obtain grants \& fiscal transfers and borrow from banks; provision for representation of women and the marginalized is made to provide voice to disadvantaged groups; institutionalization of electoral process for selection of people's representatives.

The general core weaknesses are connected with the following constraints in South Asia:

1. Decentralization is generally seen as a threat by politicians;

2. Local government institutions lack the necessary financial and human resources;

3. Local-level management capacities are inadequate;

4. Gaps exist between resource needs and availability;

5. There is a need for public-private partnership projects and activities, however a legal framework for public-private partnership is not available;

6. Lack of resources and management skills makes the local institutions ineffective.

Other partial issues can also be mentioned, like - old mind-set of the central line agencies continues to regard local bodies as subordinate agents of local development rather than autonomous units of local self-governance; despite authorization of local bodies to impose and collect taxes, service charges and fees, revenue generation by local government bodies is inadequate and they continue to depend largely on grant from central and/or provincial government; very few local bodies have been able to satisfactorily carry out the given tasks especially on account of limited institutional capability and limited financial resources; in almost all the local government bodies represent more than one party and partisan political interests influence the functioning of the local bodies. In some cases, conflicting interests have stalled the functioning of local bodies. Partisan political affiliations also affect the relation of local bodies with the central government if the latter is formed by a rival political party; usually local bodies have not been effective in terms of inclusion and participation at local level in 
governance due to lack of financial resources, poor institutional capabilities, partisan politics and absence of real autonomy.

The processes of empowering local governments in the region are connected with many opportunities, especially - multilateral and bilateral development agencies are giving priority to decentralization issues; political parties and the intelligentsia are largely in favour of decentralization and local self-governance; Local bodies can be training grounds for developing political and social leadership; Setting up a local development-oriented civil service accountable to local bodies can help in attracting professionals to local bodies.

The core threats are as follows - The centralized political culture impedes the process of decentralization; Non-implementation of legislative provisions in spirit by many provincial governments, including the bureaucracy, poses a high degree of uncertainty for proper functioning of local governments; With transparency and accountability practices and supervision, monitoring and evaluation weak at central and provincial levels, narrow partisan and political biases thrives at the local level; Fiscal decentralization remains neglected.

Effective service delivery requires central, provincial and local actions, such as streamlining budget spending processes and procedures; enhancing local revenue mobilization; promoting transparency, mechanisms of accountability, and citizens' voice; improving incentives for performance; and building systems to monitor outcomes and support capacity building. Key improvements in decentralization of public services to the local tiers will continue to depend on the political commitment to strengthening local governance.

Common challenges in the region therefore include - development of institutional capacity; clear distinction of roles and functions at different levels of the local governments; clear definition of fiscal transfer systems from central government to local governments; improved accountability and responsibility, improved authority; and provision of adequate human and financial resources.

Democratic decentralization supported by social mobilization is a powerful tool for poverty alleviation. However, it faces a renewed local level resource mobilization strategy, therefore, requires a changed approach that recasts sources of tax and nontax revenue for different strata of local government.

It is often said that the powers and functions that have been devolved to local bodies for which they are not prepared. The first and the foremost challenge for effective local governance is enhancing the capabilities of local bodies. This requires coordinated efforts among local bodies, government, donors, NGOs and training centres. Moreover, local body autonomy is greatly restricted by the dependence on central grants and local government institutions need technical support for mobilizing internal or own resources. It is equally important for the central bureaucracy to change its mind-set and the political leadership to have trust in local bodies. 


\section{Conclusion}

1. Decentralization is a sine-qua-non for the eradication of poverty and hunger in this region and this is why decentralization processes progress step by step in South Asia. However, our paper suggests that a lot needs to be done with the aim to increase local government capacities in the region.

2. First, it is essential to have a strong political commitment for decentralized governance. This is to be followed by strong and clear legislative implementation of demarcation of role and function between central line ministries, local bodies, civil society organizations as well as different layers of local bodies and other stakeholders including NGOs.

3. Second, fiscal federalism system shall be created - like the legislative provisions for inter-governmental transfers like sharing of revenue and tax proceeds; common property resources and borrowing by local bodies from financial institutions need priority attention. Streamlining budget spending processes and procedures and enhancing local revenue mobilization can help to solve also situations when the actual demand for physical and social infrastructure at the local level far exceeds the availability of financial resources from local tax and non-tax income as well as the annual grants from the government. Another aspect that needs focus is enabling financial resource mobilization capacity through increased share of national resources for local bodies, direct assignment of taxes, formula-based distribution of available resources among local body levels, reduction in regional disparities and provision of subsidy to poorer regions, reduction in administrative expenditure, community participation with matching contribution, improvement for efficient tax collection and account keeping.

4. Third, effective service delivery requires central, provincial and local actions, such as: (promoting transparency, mechanisms of accountability, and citizens' voice; improving incentives for performance; and building systems to monitor outcomes and support capacity building. Key improvements in decentralization of public services to the local tiers will continue to depend on the political commitment to strengthening local governance.

5. Fourth, capacity building measures for local bodies are of paramount importance to make these institutions self-sufficient, efficient and effective. Capacity building initiatives include establishment of systems - manuals, guidelines, direction, networking and partnership, openness and transparency, timely dissemination of information, right to access information through the use of information technology, and human resource development. The blurred line between elected representatives and officers is again something which needs to find convergence. Further, to ensure capacity building at organizational and human levels, it is important to build up a dedicated cadre for local government having the requisite skill and aptitude.

6. Common challenges in the region also include - development of institutional capacity; clear distinction of roles and functions at different levels of the local governments; clear definition of fiscal transfer systems from central government to 
local governments; improved accountability and responsibility, improved authority; and provision of adequate human and financial resources.

7. The final concluding lesson is that South Asia is in midst of transition and reforms for democratic decentralization is in progress. The road is long and tortuous, but is the only 'one-way' path to alleviation of poverty, inclusive growth, participatory planning and providing equality and justice to the people.

\section{References}

1. Act on the Decentralization of the Administrative Divisions of the Maldives, 2010, Government of the Republic of Maldives, Ministry of Home Affairs.

2. An Assessment of Afghanistan's Municipal Governance Framework, August 2011, IDG Working Paper No. 2011-03, (Jamie Boex, Grace, Buencamino, and Deborah Kimble), Urban Institute Centre on International Development and Governance.

3. Annual Report, 2011-12 of Local Government Department, Ministry of Local Government, Area Development and Cooperative, Government of Republic of Bangladesh.

4. Bhutan National Urbanisation Strategy, Royal Government of Bhutan, 2008, Royal Government of Bhutan, Ministry of Works \& Human Settlement (Policy \& Planning Division), with funding support from Cities Alliance (The World Bank), prepared by Infrastructure Professionals Enterprise (P) Ltd., India in association with Gyaltshen Consultancy Services, Bhutan.

5. Capacity Development of Local Government Institutions in South Asia: Experiences from South Asia, Priya Global Partnership, India.

6. Democracy in South Asia, by Dr Rohit Kumar Nepali, PhD, Executive Director for the South Asia Partnership International, Kathmandu, Nepal, 2009, International Institute of Democracy and Electoral Assistance, Stockholm, Sweden.

7. Development Councils (Amendment) Act, 1981 (No. 45 of 1981), Government of the Democratic Socialist Republic of Sri Lanka.

8. Development Councils Act, 1980 (No. 35 of 1980) Development Councils (Amendment) Act, 1981 (No. 45 of 1981), Government of the Democratic Socialist Republic of Sri Lanka.

9. Developmental Local Government:Putting Local Government at the Heart of Development, Commonwealth Local Government Conference, Kampala, Uganda, 14 to 17 May 2013.

10. Devolution Row: An assessment of Pakistan's 2001 Local Government Ordinance, The Report for the Research Project -"The Political Economy of State Building" - The Pakistan Case Study, (November 2010), Conflict Research Unit, Netherlands Institute for International Relations, 'Clingendael'.

11. Jawaharlal Nehru National Urban Renewal Mission Project Documents and Guidelines, Ministry of Urban Development, Government of India, www.mhupa.gov.in/PQAS/jnnurm.pdf.

12. Local Council Election Act, 2010 (N0. 10 of 2010), Government of the Republic of Maldives, Ministry of Home Affairs. 
13. Local Self Governance Act, 2055 (1999), His majesty’s Government, Ministry of Law \& Justice.

14. Pradeshiya Sabhas Act, 1987 (No. 15 of 1987), Government of the Democratic Socialist Republic of Sri Lanka.

15. Pro-poor Growth and Governance in South Asia-Decentralization and Participatory. Development, P. Wignaraja, The Pakistan Development Review, Part II (Winter 2005) pp. 1159-1171.

16. The Bhutan Municipal Act, 1999, Royal Government of Bhutan, Ministry of Works \& Human Settlement.

17. The Constitution (Seventy-Fourth Amendment) Act, 1992, Government of India.

18. The Constitution (Seventy-Third Amendment) Act, 1992, Government of India.

19. The Urban Governance and Infrastructure Improvement Project in Bangladesh: Sharing Knowledge on Community Driven Development, 2012, Asian Development Bank, Manila, Philippines.

20. Thirteenth Amendment (13 A) to the Constitution of Sri Lanka passed by the parliament of Sri Lanka on $14^{\text {th }}$. November 1987.

\title{
Amitava Basu
}

\section{Vietos valdžios gebẻjimai Pietų Azijoje}

\author{
Anotacija
}

Pietų Azijai, kurios plotas yra 4,48 milijonai kvadratinių kilometrų, priklauso septynios šalys: Bangladešas, Butanas, Indija, Maldyvai, Nepalas, Pakistanas ir Šri Lanka. Šiame regione gyvena apytiksliai 34 proc. visų Azijos gyventojų ir daugiau nei 16,5 proc. visų pasaulio gyventojų. Pietų Azija išgyveno ilgą spartaus ekonominio augimo, siekiančio vidutiniškai 6 proc. per metus, laikotarpị. Nors neturtingujų dalis šiuo metu Pietų Azijoje nuo 1981 m. yra pati mažiausia nei bet kada anksčiau, tačiau šis regionas išlieka pats neturtingiausias pasaulyje po Afrikos sub-Sacharos regiono. Visame Pietų Azijos regione demokratija yra silpnai išsivysčiusi, korupcija yra išaugusi, o žmogaus teisių dažnai nepaisoma. 1993 m. balandžio mènesį Pietų Azijos valstybių vadovai vienbalsiai nutarè sumažinti skurdą. Šis susitarimas Pietų Azijoje atvèrė naujas politines galimybes, davusias pradžią valdžios decentralizacijai šiame regione. Nors politinė decentralizacija vyksta, tačiau fiskalinė ir administracinè decentralizacija atsilieka daugumoje Pietų Azijos valstybių. Decentralizacija lèmé vietos valdžios institucijų atsiradimą, jų konstitucinį ịtvirtinimą ir igalinimą. Kaip demokratizacijos dalis atsirado renkami vietos valdžios atstovai, priimantys politinius sprendimus ir kuriantys strategijas, o vykdomosios institucijos igyvendina ir atlieka kasdienes funkcijas. Didžiausias iššūkis siekiant efektyvaus vietos valdymo yra vietos valdžios institucijų gebejjimų stiprinimas - šiose institucijose dirbantys tarnautojai turi būti adekvačiai išmokyti ir aprūpinti užduotims atlikti būtinais ištekliais. Vietos valdžios institucijų veiklos sėkmè taip pat priklauso nuo politinès valios ir aiškaus vietos valdžios institucijų reglamentavimo. Pietų Azija yra perejjimo i demokratinę decentralizaciją ir reformų pusiaukeleje. Šis kelias yra ilgas ir skausmingas, tačiau tai vienintelis kelias i skurdo sumažejjimą, įtraukiantị augimas ir dalyvaujamajji valdymą. 
Amitava Basu - Development Practitioner and President of Intercontinental Consultants and Technocrats Private Limited, New Delhi, India E-mail.: abasu@ictonline.com

Amitava Basu - vystymo srities specialistas, kompanijos „Tarpkontinentiniai konsultantai ir technokratai“" prezidentas (Naujasis Delis, Indija)

E.paštas: abasu@ictonline.com

Straipsnis įteiktas redakcijai 2015 m. rugpjūčio mėn.; recenzuotas; parengtas spaudai $2015 \mathrm{~m}$. rugsejo mèn. 